International Research Journal of Management, IT \& Social Sciences
Available online at https://sloap.org/journals/index.php/irjmis/
Vol. 6 No. 4, July 2019, pages: 73 85
ISSN: 2395-7492
https://doi.org/10.21744/irjmis.v6n4.652

\title{
Effect of Empowerment and Compensation on Performance of Honorary Employees Mediated by Organizational Commitments
}

Ni Putu Ayu Widyastuti a

I Gede Riana ${ }^{b}$

Article history:

Received: 27 March 2019

Accepted: 31 May 2019

Published: 15 June 2019

\section{Keywords:}

commitment;

compensation;

employee;

empowerment;

performance;

\begin{abstract}
The purpose of this study to analyze the influence of empowerment and compensation on employee performance is mediated by organizational commitment. The study was conducted by distributing questionnaires to a sample of 100 honorary employees in regional organizations in Denpasar using the proportionate random sampling method. The analytical method used is Partial Least Square (PLS) analysis. The results of PLS analysis show that empowerment, compensation, and organizational commitment have a positive and significant direct effect on employee performance. Finally, organizational commitment has a positive and significant effect on mediating empowerment and compensation for employee performance. The results of this study imply that empowerment and compensation are important factors in improving employee performance. In addition, the mediating role of organizational commitment can also contribute to improving performance. The management of each regional apparatus organization in Denpasar City needs to pay attention to these matters so that organizational goals can be achieved.
\end{abstract}

2395-7492@ Copyright 2019. The Author. This is an open-access article under the CC BY-SA license (https://creativecommons.org/licenses/by-sa/4.0/) All rights reserved.

Author correspondence:

Ni Putu Ayu Widyastuti,

Faculty of Economics and Business, Udayana University, Denpasar, Indonesia

Email address: widyasutiayu@gmail.com

\section{Introduction}

In improving the performance of employees, the organization will do several ways that can encourage employees to work optimally. Based on research conducted if Ibrahin \& Haim (2016), organizational commitment factors, empowerment, and compensation have a positive influence in improving performance. The study explains that there are direct and indirect effects between variables on performance where empowerment and compensation factors have a direct influence on performance and there are indirect effects of organizational commitment as mediation.

\footnotetext{
${ }^{\text {a }}$ Faculty of Economics and Business, Udayana University, Denpasar, Indonesia ${ }^{\mathrm{b}}$ Faculty of Economics and Business, Udayana University, Denpasar, Indonesia
} 
Organizational commitment is one factor in improving employee performance. Employees who have a high commitment to the organization will be loyal to the goals of the organization through good performance (Indayanti, 2012). Adnan (2015), in his research, mentions organizational commitment as a measure of the strength of identity and employee involvement in organizational goals and values.

Organizational commitment shows the psychological attachment of an individual to an organization and is also considered as an individual's attitudes and behavior towards the goals of an organization. Organizational commitment is not only related to the level of entry and exit of employees but also related to the willingness of employees to sacrifice for the organization, (Vivienne et al., 2012).

Some research shows that there is a positive and significant influence between organizational commitment on employee performance. Research conducted by Ali (2010), and Indayanti (2012), states that organizational commitment has a positive and significant effect on performance. Employees who have a high commitment to the organization will be loyal to the goals of the organization through good performance. Adnan (2015) in his research mentions organizational commitment as a measure of the strength of identity and employee involvement in organizational goals and values. Organizational commitment shows the psychological attachment of an individual to an organization and is also considered as an individual's attitudes and behavior towards the goals of an organization.

Organizational commitment will show the efforts of an employee in carrying out his work, loyal to his institution by exerting extra effort to achieve goals and identify employees in meeting organizational goals (Haq et al., 2014). Low commitment can be caused by many things, but often it is potentially because people in the organization do not know what they can get with the job, people become unhappy with their work, they become bored, apathetic and ultimately unproductive (Wijoyo, 2016).

In the world of work, the stipulation of employee empowerment is the center of a strategy that influences the success of employees to achieve goals, in the sense that employee empowerment is broader than the term participating. According to Astuti et al., (2013), employee empowerment is a form of employee engagement planned by management that aims to generate organizational commitment and increase contributions to the organization. Organizations that do not develop and empower employees and close themselves from change, then they will only be spectators and not players (Yulianti, 2011).

Past studies on empowerment show a close relationship between empowerment of workgroup performance and innovative behavior (Fernandez \& Moldogaziev, 2011; Fernandez \& Moldogaziev, 2013). The study of previous empowerment mostly has a focus on learning the relationship between empowerment and direct performance (Maynard et al., 2014), wherein the study stated that there is a positive and significant influence of empowerment on employee performance.

Empowerment of employees carried out by the organization can spur an increase in creativity, motivation and innovative power possessed by each employee in carrying out their duties and responsibilities (Kazlauskaite et al., 2012). The existence of an employee empowerment program is expected to increase employee performance. So that the company's goals will be achieved well, fast and flexible.

Another factor that can affect performance is compensation. Compensation is a form of remuneration received by employees in the form of financial and non-financial. In general, compensation relates to the suitability of the amount received associated with performance achievement, as well as remuneration in the form of career benefits namely security, self-development, career system clarity and social rewards (praise and appreciation) (Rustini, 2015). Compensation is one of the factors that motivate employees to commit to the organization. Besides that, good compensation will foster a sense of belonging to the organization, which has an impact on an increasing commitment to the organization (Endriani, 2016).

Research conducted by Kasenda (2013), shows that compensation has a significant effect on employee performance with a coefficient value that is positive. In addition, compensation and rewards also have a major impact on the performance of employees of oil and gas companies (Khan, 2010). In essence, existing studies have acknowledged compensation as a motivational tool used by organizations as an increase in employee performance (Harris \& McMahan, 2015). More precisely, these studies show a significant positive relationship between the factors that influence employee performance where compensation is a series of methods used (Shin \& Konrad, 2014).

Article 93 - Article 107 of the ASN Law states that honorary workers have the right to receive compensation in the form of salaries and benefits, leave, protection and competence development. However, in the reality that occurs in the field itself, compensation is only around salary and protection in the form of providing health benefits. As mentioned above, the utilization of temporary employees is carried out to the maximum even more than civil servants, of course, it can be seen that it is not worth the compensation was given. Moreover, temporary staff lacked opportunities in competency development such as following technical guidance and training related to the tasks assigned. If this 
continues then over time it can affect the honor of honorary employees of the organization and have an impact on the commitment and performance of honorary employees themselves (Delgado et al., 2018; Nasution, 2016).

\section{Literature Review \& Hypothesis Development \\ The Effect of Empowerment on Employee Performance}

Research on empowerment through additional policies submitted to employees enables them to demonstrate flexibility, improve service quality, facilitate adaptation to unexpected circumstances, and use time more productively, which ultimately affects performance significantly (Fernandez \& Moldogaziev, 2013; Ibrahin \& Haim, 2016). Even though employee empowerment is an important means that enables employees to carry out their duties more effectively through increasing capabilities, competencies and technical knowledge (Fernandez \& Moldogaziev, 2011), their effectiveness is measured by how it affects employee efforts which will ultimately result in organizational performance (Fernandez \& Moldogaziev, 2013). Previous studies on empowerment showed a close relationship between empowerment and organizational commitment, workgroup performance and innovative behavior (Fernandez \& Moldogaziev, 2011; Fernandez \& Moldogaziev, 2013). The study of previous empowerment mostly has a focus on learning the relationship between empowerment and direct performance (Maynard et al., 2014), wherein the study stated that there is a positive and significant influence of empowerment on employee performance. Based on the discussion above, this study has the following hypothesis (Hidayat \& Budiatma, 2018).

H1: Empowerment has a positive and significant effect on employee performance.

\section{The Effect of Compensation on Employee Performance}

Compensation can be interpreted as financial or non-financial rewards received by employees as wages for their efforts and talents devoted to the production of goods and services for an organization. Effective compensation management means the act of implementing and designing a payment system that guarantees the ability of an organization to attract, maintain, and maintain a group of capable employees, willing and able to work well as needed so that the organization can achieve its objectives (Lo et al., 2011). However, an effective organizational compensation system must be able to channel individuals according to the organization's strategic goals (Fisher et al., 2007). In addition, apart from the relationship of compensation strategies with awards that are effective in influencing employee motivation which ultimately surpasses overall organizational results, this is an aspect that still needs to be further investigated (Gupta \& Shaw, 2013). Among studies limited in this field, there is empirical evidence supporting that compensation that is large and in line with the quality of service orientation affects the profitability of the organization (Georgiadis \& Pitelis, 2012). This is supported by research conducted by Kasenda (2013), which shows that compensation has a significant effect on employee performance with a coefficient value that is positive. In addition, compensation and rewards also have a major impact on the performance of employees of oil and gas companies (Khan, 2010). In essence, existing studies have acknowledged compensation as a motivational tool used by organizations as an increase in employee performance (Harris \& McMahan, 2015). More precisely, the research shows a fairly positive relationship between performance factors on employee performance where compensation is one of a series of methods used (Shin \& Konrad, 2014). Based on the above, this study has the following hypothesis.

H2: Compensation has a positive and significant effect on employee performance.

\section{The Effect of Empowerment on Organizational Commitments}

Pratiwi (2012), in his research, stated that there is a direct influence between empowerment and organizational commitment, thus it can be said that through empowerment will have personal control about how to do work and have confidence in the ability possessed with results in the form of organizational commitment. Similar research was also conducted by Fitriah (2015), which identified that employee empowerment had a positive and significant influence on organizational commitment. The implication that is obtained is that the higher the empowerment given by the company to the employee, the more commitment that the employee has, such as the sense of loyalty that the employee has towards the company. Based on the results of the above studies, the hypothesis is made as follows (Sudharma et al., 2018; Yunita et al., 2019).

H3: Empowerment has a positive and significant effect on organizational commitment

Widyastuti, N. P. A., \& Riana, I. G. (2019). Effect of empowerment and compensation on performance of honorary employees mediated by organizational commitments. International Research Journal of Management, IT and Social Sciences, 6(4), 73-85. https://doi.org/10.21744/irjmis.v6n4.652 


\section{The Effects of Compensation on Organizational Commitments}

Nawab \& Bhatti (2011), examined the effect of compensation and job satisfaction on organizational commitment. The results show that compensation and job satisfaction have a positive effect on organizational commitment. Anvari et al., (2011), suggested that compensation is closely related to organizational commitment, the results of his research indicate that compensation has a positive effect on organizational commitment. Other studies such as by Alamelu $e t$ al., (2015), in the manufacturing industry in India, shows that employee compensation for commitment has a significant and positive influence. Then, Kee et al., (2016), in the banking industry in Malaysia showed a significant influence between the relationship of compensation and commitment. In the food industry in Kenya carried out by Milgo et al., (2014), showed a significant influence between compensation and commitment. Endriani (2016), in his research also shows that compensation variables have a significant positive effect on organizational commitment. Based on the results of the above studies, the hypothesis is made as follows.

H4: Compensation has a positive and significant effect on organizational commitment

\section{The Effect of Organizational Commitment on Employee Performance}

Employee attitudes and attitudes are assessed based on the direct and indirect impacts they have and how significantly they contribute to overall organizational performance (Jung \& Yoon, 2014). In essence, human resources are very important in business organizations due to their direct influence on organizational performance through their relationships with clients in the service industry (Wallace et al., 2011). The need to get a commitment from employees, in particular, upholding the strategic role of human resources is very important for the organization and this situation requires companies to build an organizational system that is appropriately oriented towards employee commitment (Kim \& Sung-Choon, 2013). In addition, organizational commitment also influences the efforts of more employees (Kim \& Brymer, 2011), so organizations need to continually strive to increase employee commitment (Khanin, 2013) because this aspect can help reduce the tendency of employees to leave the organization (Nouri \& Parker, 2013; Tse et al., 2013) and positively affect overall performance (Ali et al., 2010). In addition to organizational commitment it is known to be closely related to the quality of performance (Fu \& Deshpande, 2014), empowerment of organizational membership behavior (Huang et al., 2012; Oh \& Chung, 2011), quality of performance (Imran et al., 2014) and employee performance (Ali et al., 2010). This also leads to the organizational commitment that leads to the extra effort which ultimately affects competitive performance (Kim \& Brymer, 2011). Based on the results of the above studies, the hypothesis is made as follows.

H5: Organizational commitment has a positive and significant effect on organizational performance.

The Effect of Relationship between Organizational Commitment as Mediation between Empowerment, Compensation, and Organizational Performance

Basically, when employees see their relationship with the organization as a social relationship, they tend to feel more satisfied with their work, focus more on the organization, have a feeling of personal achievement in the work, and can help other employees in carrying out their tasks (Venkataramani et al., 2010). Social relationships themselves depend on positive reactions from others. This aspect is a two-way relationship involving mutually beneficial procedures and a unity involving an exchange in social relations (Blau, 1964). Organizational commitment according to Meyer et al., (2002), can be interpreted as emotional attachment, identification, and involvement of individuals with organizations and the desire to remain a member of the organization. The response system provided by the organization sometimes gets less attention from employees to foster a more loyal attitude, this is due to the concern that employees will get sanctions if they submit their complaints. Therefore it is necessary to have high trust and organizational support for employees as an important thing for each member of the organization, in this case, an increase in compensation (Windy \& Gunasi, 2012). Karavardar (2014), conducted a study stating that there was a mediating role of organizational commitment in the relationship between empowerment and organizational performance.

Irvan et al., (2013), in his research, proved that organizational commitment was able to mediate the positive impact of compensation on employee performance. Adnan (2015), proves that the same organizational commitment can mediate the positive effects of compensation in improving employee performance in the company. Hueryren \& Dachuan (2012), positively the effect of compensation on improving employee performance is mediated by organizational commitment. Based on the results of the above studies, the hypothesis is made as follows.

H6a: Organizational commitment mediates the effect of empowerment on employee performance. 
H6b: Organizational commitment mediates the effect of compensation on employee performance.

\section{Materials and Methods}

The population in this study were all honorary employees who worked on OPD in the City of Denpasar as many as 1,083 people by calculating the sample size using Slovin techniques. The Slovin formula for determining samples is as follows.

$$
\mathrm{n}=\frac{N}{1+N(e)^{2}}
$$

The population in this study is 1,083 employees, so the percentage of allowance used is 10 percent and the calculation results can be rounded up to achieve conformity. So to find out the research sample, with the calculation as follows:

$$
\begin{aligned}
n & =\frac{\mathrm{N}}{1+\mathrm{N}(\mathrm{e})^{2}} \\
= & \frac{1083}{1+1083(0,1)^{2}} \\
& =91,54 \\
& =92(\text { ruled })
\end{aligned}
$$

The calculation results show the number of samples taken is a minimum of 92 units with fault tolerance $(\alpha=10 \%)$. To test the hypothesis and produce a feasible model, this study uses the Structural Equation Model (SEM) with variance based or component-based approach with Partial Least Square (PLS).

\section{Results and Discussions}

Table 1

$\mathrm{R}^{2}$ Testing Result

\begin{tabular}{ll}
\hline Variable & $R$-square \\
\hline Organizational Commitment & 0.368 \\
Employee Performance & 0.466 \\
\hline
\end{tabular}

Primary Data, 2019

Predictive-relevance $\mathrm{Q} 2$ value is obtained by the formula:

$$
\begin{aligned}
& \mathrm{Q}^{2}=1-\left(1-\mathrm{R}_{1}^{2}\right)\left(1-\mathrm{R}_{2}^{2}\right) \\
& \mathrm{Q}^{2}=1-(1-0,368)(1-0,466) \\
& \mathrm{Q}^{2}=1-(0,632)(0,534)=\mathrm{Q} 2=1-0,3375=\mathrm{Q}^{2}=0,6625
\end{aligned}
$$

The calculation results show a predictive-relevance value of $0.6625(>0)$. That means that 66.25 percent variation in employee performance variables (dependent variables) can be explained by the variables used in the research model, namely empowerment, compensation, and organizational commitment. While the remaining 33.75 percent is explained by other variables that are outside the research model.

\section{Direct Effect Testing}

The basis used in testing the hypothesis is the value found in the output path coefficients presented in Table 2.

Widyastuti, N. P. A., \& Riana, I. G. (2019). Effect of empowerment and compensation on performance of honorary employees mediated by organizational commitments. International Research Journal of Management, IT and Social Sciences, 6(4), 73-85. https://doi.org/10.21744/irjmis.v6n4.652 
Table 2

Direct Effect

\begin{tabular}{|c|c|c|c|c|c|}
\hline & $\begin{array}{l}\text { Original Sample } \\
\text { Estimate }\end{array}$ & $\begin{array}{l}\text { Mean of } \\
\text { Subsamples }\end{array}$ & $\begin{array}{l}\text { Standard } \\
\text { Deviation }\end{array}$ & t-Statistic & Information \\
\hline $\begin{array}{l}\text { Empowerment -> Employee } \\
\text { Performance }\end{array}$ & 0.335 & 0.332 & 0.112 & 3.004 & Significant \\
\hline $\begin{array}{l}\text { Compensation -> Employee } \\
\text { Performance }\end{array}$ & 0.230 & 0.224 & 0.091 & 2.529 & Significant \\
\hline $\begin{array}{l}\text { Empowerment-> Organizational } \\
\text { Commitment }\end{array}$ & 0.318 & 0.331 & 0.091 & 3.495 & Significant \\
\hline $\begin{array}{l}\text { Compensation -> Organizational } \\
\text { Commitments }\end{array}$ & 0.405 & 0.397 & 0.102 & 3.987 & Significant \\
\hline
\end{tabular}

Primary Data, 2019

Hypothesis testing is done using t-statistics. If the value of t-statistics $\geq$ t-table value (1.96), then Ho is rejected and the research hypothesis is accepted. Table 2 shows that the hypothesis of direct influence in this study was entirely accepted.

\section{Mediation Effect Testing}

The test of the mediating role of organizational commitment on the influence of empowerment and compensation on employee performance by examining the coefficient of direct-indirect influence of empowerment variables and compensation for employee performance variables through organizational commitment can be shown through table 3 .

Table 3

Indirect Effect

\begin{tabular}{lllllr}
\hline & $\begin{array}{l}\text { Original Sample } \\
\text { Estimate }\end{array}$ & $\begin{array}{l}\text { Mean of } \\
\text { Subsamples }\end{array}$ & $\begin{array}{l}\text { Standard } \\
\text { Deviation }\end{array}$ & t-Statistic & Information \\
\hline $\begin{array}{l}\text { Empowerment -> Organizational } \\
\text { Commitment -> Employee }\end{array}$ & 0.114 & 0.118 & 0.053 & 2.177 & Significant \\
$\begin{array}{l}\text { Performance. } \\
\begin{array}{l}\text { Compensation -> Organizational } \\
\text { Commitment -> Employee }\end{array}\end{array}$ & 0.090 & 0.098 & 0.043 & 2.066 & Significant \\
Performance. & & & &
\end{tabular}

Primary Data, 2019

Table 3 has shown that the effect of empowerment and compensation variables on performance variables through organizational commitment variables (Effect D) is significant. The total results of the hypothesis test influence of variables in this study are shown in Table 4 as follows:

Table 4

Hypothesis Testing Result

\begin{tabular}{|c|c|c|c|c|c|}
\hline & $\begin{array}{l}\text { Original Sample } \\
\text { Estimate }\end{array}$ & $\begin{array}{l}\text { Mean of } \\
\text { Subsamples }\end{array}$ & $\begin{array}{l}\text { Standard } \\
\text { Deviation }\end{array}$ & t-Statistic & Information \\
\hline $\begin{array}{l}\text { Empowerment -> Employee } \\
\text { Performance }\end{array}$ & 0.335 & 0.332 & 0.112 & 3.004 & Significant \\
\hline $\begin{array}{l}\text { Compensation -> Employee } \\
\text { Performance }\end{array}$ & 0.230 & 0.224 & 0.091 & 2.529 & Significant \\
\hline $\begin{array}{l}\text { Empowerment-> Organizational } \\
\text { Commitment }\end{array}$ & 0.318 & 0.331 & 0.091 & 3.495 & Significant \\
\hline
\end{tabular}




\begin{tabular}{|c|c|c|c|c|c|}
\hline $\begin{array}{l}\text { Compensation -> Organizational } \\
\text { Commitment }\end{array}$ & 0.405 & 0.397 & 0.102 & 3.987 & Significant \\
\hline $\begin{array}{l}\text { Organizational Commitment -> } \\
\text { Employee Performance }\end{array}$ & 0.282 & 0.297 & 0.100 & 2.826 & Significant \\
\hline $\begin{array}{l}\text { Empowerment -> Organizational } \\
\text { Commitment -> Employee } \\
\text { Performance. }\end{array}$ & 0.114 & 0.118 & 0.053 & 2.177 & Significant \\
\hline $\begin{array}{l}\text { Compensation -> Organizational } \\
\text { Commitment -> Employee } \\
\text { Performance. }\end{array}$ & 0.090 & 0.098 & 0.043 & 2.066 & Significant \\
\hline
\end{tabular}

Table 4 shows that the influence of empowerment and compensation variables on organizational commitment variables (Effect B) is significant, the effect of organizational commitment variables on employee performance variables (Effect C) is significant, the direct effect of empowerment variables and compensation on employee performance variables (Effect A) is significant, it is said to be partial mediation. Thus, organizational commitment as a partial mediation between the influence of empowerment and compensation for employee performance. This can be interpreted as empowerment variable and compensation as exogenous variables can influence employee performance as endogenous variables directly without going through / involving organizational commitment variables which act as mediating variables.

\section{The Effect of Empowerment on Employee Performance}

The results of the analysis using PLS produce path coefficients a direct influence of empowerment on employee performance with $\beta$ values of 0.425 and t-statistics 4.319 . The value of t-statistics 4.319 is greater than 1.96 (critical point), thus, the effect of empowerment on employee performance is positive and significant. Therefore, hypothesis 1 (H1) can be accepted. This means that the better empowerment that is applied can improve employee performance. Empowerment is a means by which organizations provide the opportunities and resources needed for employees that enable them to contribute positively and encourage the changes they want to achieve in an organization (Delaney et al., 2014). Batliwala (2007), argues that in employee empowerment includes two very important issues in improving company performance, namely the concept of empowerment which has a rooted commitment and employee trust as a strategy in running the company.

The results of this study are in line with the research conducted by Maynard et al., (2014), that there is a positive relationship between empowerment and direct performance. Previous research by Laschinger et al., (2004), has shown that employees of an organization that values empowerment motivate them so they can think of better ways to carry out tasks, which also have an impact on increasing employee competency and performance, and foster a sense of duty is an important task. The research conducted by Fernandez \& Moldogaziev (2013), shows that empowerment through additional policies handed over to employees enables them to demonstrate flexibility, improve service quality, facilitate adaptation to unexpected situations, and use time more productively, which ultimately affects performance significantly. In line with previous research by Yulianti (2011), shows that empowerment has a positive and significant effect on performance so that the more empowerment given to crew members, the performance of the crew will increase.

\section{The Effect of Compensation on Employee Performance}

The results of the analysis using PLS produce path coefficients a direct effect of compensation on employee performance with $\beta$ value of 0.344 and t-statistics 4,093. The value of t-statistics 4,093 is greater than 1.96 (critical point), thus, the effect of compensation on employee performance is positive and significant. Therefore, hypothesis 2 (H2) can be accepted. This means that the higher compensation provided can improve employee performance.

Effective compensation management means the act of implementing and designing a payment system that guarantees the ability of the organization to attract, maintain, and maintain a group of capable employees, willing and able to work well as needed so that the organization can achieve its objectives (Lo et al., 2011). Kadarisman (2012), giving compensation is one of the functions of Human Resource Management (HRM) which deals with all types of individual awards in exchange for carrying out organizational tasks. Compensation is the main cost of expertise or

Widyastuti, N. P. A., \& Riana, I. G. (2019). Effect of empowerment and compensation on performance of honorary employees mediated by organizational commitments. International Research Journal of Management, IT and Social Sciences, 6(4), 73-85. https://doi.org/10.21744/irjmis.v6n4.652 
employment and loyalty in organizational activities. Providing appropriate compensation can provide benefits to employees because it can produce high performance. With the compensation program being felt fair, employees can improve their performance.

Based on the perceptions of respondents it is known that the compensation for honorary employees in the OPD of Denpasar City is still insufficient category, where for the indicator of benefits has the lowest value. This shows that if there is an increase in compensation, especially on benefits, it can improve the performance of temporary employees.

This study has results that are similar to the research conducted by Wijoyo (2016), which states compensation has a positive and significant effect on the performance of PT. Indonesian Sport Glove. In addition, research was conducted by (Khan, 2010); Georgiadis \& Pitelis, (2012); Kasenda (2013); Harris \& McMahan (2015); also have similar results.

\section{The Effect of Empowerment on Organizational Commitment}

The results of the analysis using PLS produce path coefficients the direct influence of empowerment on organizational commitment with the value of $\beta$ of 0.318 and t-statistics 3.495 . The value of t-statistics 3.495 is greater than 1.96 (critical point), thus, the effect of empowerment on organizational commitment is positive and significant. Therefore, hypothesis 3 (H3) can be accepted. This implies that the better empowerment that is applied can increase organizational commitment.

This result is in line with the research conducted by Suhermin (2012), stating that empowerment has a direct influence on organizational commitment. This means that the better the level of empowerment carried out by the organization of employees will provide an increase in organizational commitment and vice versa. Pratiwi (2012), in his research, stated that there is a direct influence between empowerment and organizational commitment, thus it can be said that through empowerment will have personal control about how to do work and have confidence in the ability possessed with results in the form of organizational commitment. Similar research was also conducted by Fitriah (2015) \& Mahiri (2017), which identified that employee empowerment had a positive and significant influence on organizational commitment. The implication that is obtained is that the higher the empowerment given by the company to the employee, the more commitment that the employee has, such as the sense of loyalty that employees have towards the organization.

\section{The Effects of Compensation on Organizational Commitments}

The results of the analysis using PLS produce path coefficients the direct effect of compensation on organizational commitment with $\beta$ value of 0.405 and t-statistics 3.987. The value of t-statistics 3.987 is greater than 1.96 (critical point), thus, the effect of compensation on organizational commitment is positive and significant. Therefore, hypothesis 4 (H4) is acceptable. This means that the higher compensation received can increase employee commitment to the organization.

Compensation is a form of financial and non-financial rewards given to employees as remuneration for the contributions they make to their organizations. Adequate compensation can be a motivation for employees to stay in the organization and unwittingly grow a sense of belonging to the organization they work for.

Based on the results of these studies, it can be understood that one of the efforts to grow and maintain employee commitment can be through compensation. The elements of compensation consisting of salaries, benefits, and facilities must receive more attention from the organization so that compensation can foster employee commitment to the organization. The results of this study are in line with the results of the study found by Handaru et al., (2013); Nawab \& Bhatti (2011).

The results of this study are also in line with the research conducted by Anvari et al., (2011), which suggests that compensation is closely related to organizational commitment, the results of his research indicate that compensation has a positive effect on organizational commitment. Other studies such as by Alamelu et al., (2015); Kee et al., (2016) and Milgo et al., (2014); showed a significant influence between compensation and commitment. Endriani (2016), in his research also shows that compensation variables have a significant positive effect on organizational commitment.

\section{The Effect of Organizational Commitment on Employee Performance}

The results of the analysis using PLS produce path coefficients a direct effect of organizational commitment on employee performance with $\beta$ value of 0.282 and $t$-statistics 2,286 . The value of $t$-statistics is 2,286 greater than 1.96 (critical point), thus, the influence of organizational commitment on employee performance is positive and significant. 
Therefore, hypothesis 5 (H5) is acceptable. This means that the higher the commitment of employees can improve performance.

Employee commitment to the organization will make employees loyal to the organization and work well for the benefit of the organization. This situation is very good for achieving organizational goals because the organization gets full support from its members so that it can concentrate fully on priority goals. To create an organizational commitment, the organization really needs to pay attention to aspects that affect organizational commitment.

The results of this study are consistent with the results of previous studies conducted by Ali (2010) and Indayanti (2012) where organizational commitment has a positive and significant effect on performance. Employees who have a high commitment to the organization will be loyal to the goals of the organization through good performance. Adnan (2015), in his research, mentions organizational commitment as a measure of the strength of identity and employee involvement in organizational goals and values. Organizational commitment shows the psychological attachment of an individual to an organization and is also considered as an individual's attitudes and behavior towards the goals of an organization. Haq et al., (2014), also mention that organizational commitment will show the effort of an employee to carry out his work, be loyal to his institution by exerting extra effort to achieve goals and identify employees in meeting organizational goals.

\section{The Effect of Empowerment, Compensation on Employee Performance is mediated by Organizational Commitment Empowerment variables on employee performance are mediated by commitment}

The results of the analysis in Table 2 show the effect of empowerment variables on employee performance through organizational commitment $\beta$ value of 0.090 and t-statistics of 2.066 . The value of t-statistics is 2.066 greater than 1.96 (critical point). Therefore, hypothesis $6 \mathrm{a}(\mathrm{H6a})$ is acceptable. So there is a positive and significant indirect effect between the empowerment variables on employee performance through organizational commitment. For the indirect influence of the empowerment variable on employee performance through organizational commitment, it can be explained that the better the empowerment carried out by the organization towards employees, there is an increase in commitment and ultimately can improve employee performance. The value of indirect effect empowerment on employee performance through commitment shows a strong and significant influence. Empowered employees have a sense of self-determination which is free to make choices about how to do their own work. Through organizational commitment, an employee will feel the alignment between personal goals and organization that lead to increased employee performance.

\section{The compensation variable for employee performance is mediated by organizational commitment}

The results of the analysis in Table 2 show the effect of compensation variables on employee performance through organizational commitment $\beta$ values of 0.114 and t-statistics 2.177 . The value t-statistics 2.177 is greater than 1.96 (critical point). Therefore, hypothesis $6 \mathrm{~b}$ (H6b) is acceptable. So there is a positive and significant indirect effect between compensation variables on employee performance through organizational commitment. For the indirect effect of compensation variables on employee performance through the organizational commitment, it can be explained that the higher compensation received by employees there is an increase in commitment and ultimately can improve employee performance. The indirect effect of compensation on employee performance through commitment shows a strong and significant influence. Giving compensation in accordance with the needs and the burden of the given task will foster the motivation of employees to survive in the organization which results in increased employee performance.

The results of the elaboration above can be concluded that organizational commitment variables have a positive and significant influence as mediating between empowerment variables and compensation for employee performance variables. The results of this study also have results similar to some of the studies conducted by Jaiswal et al., (2015); Wang et al., (2014); Irvan et al., (2013); Adnan (2015); Hueryren \& Dachuan (2012) and, Ibrahim \& Haim (2016).

\section{Conclusion}

The results of the study show that there is still a low aspect of freedom (autonomy) in work carried out by honorary employees. In the future, employers are expected to be more honorary employees to give jobs because employees who have freedom in their jobs can be motivated to create a better way of performing their duties, which results in increased competence and performance. Compensation given to temporary employees is still quite low, especially in the aspect

Widyastuti, N. P. A., \& Riana, I. G. (2019). Effect of empowerment and compensation on performance of honorary employees mediated by organizational commitments. International Research Journal of Management, IT and Social Sciences, 6(4), 73-85. https://doi.org/10.21744/irjmis.v6n4.652 
of benefits. Allowances given to honorary employees are still quite minimal so that they are considered inadequate to fulfill their needs and not in accordance with the workload given. Denpasar City OPD should pay more attention to this because giving compensation that is in accordance with the needs and tasks assigned will foster the motivation of employees to survive in the organization which results in increased employee performance.

\section{Conflict of interest statement and funding sources}

The authors declared that they have no competing interest.

\section{Statement of authorship}

The authors have a responsibility for the conception and design of the study. The authors have approved the final article.

\section{Acknowledgments}

The authors would like to thank the Editor of IRJMIS for their valuable time, support, and advice in completing the current study. 


\section{References}

Ahmad, H., Ahmad, K., \& Shah, I. A. (2010). Relationship between job satisfaction, job performance attitude towards work and organizational commitment. European Journal of Social Sciences, 18(2), 257-267.

Alamelu, R., Surulivel, S. T., Motha, L. C. S., Amudha, R., \& Selvabaskar, S. (2015). Correlates of Employee Compensation and Commitment. Mediterranean Journal of Social Sciences, 6(5), 335.

Ali, I., Rehman, K. U., Ali, S. I., Yousaf, J., \& Zia, M. (2010). Corporate social responsibility influences, employee commitment and organizational performance. African journal of Business management, 4(13), 2796-2801.

Anvari, R., Amin, S. M., Ahmad, U. N. U., Seliman, S., \& Garmsari, M. (2011). The relationship between strategic compensation practices and affective organizational commitment. Interdisciplinary journal of research in business, 1(2), 44-55.

Batilwala, S. (2007). Taking The Power Out of Empowerment. India based Civil Society Research Fellow. Hauser Center for Nonprofit Organizations, Harvard University.

Blau, P. M. (1964). Justice in social exchange. Sociological Inquiry, 34(2), 193-206. https://doi.org/10.1111/j.1475682X.1964.tb00583.X

Chang, N., Irvan, M., \& Terano, T. (2013). A TV program recommender framework. Procedia Computer Science, 22, 561-570. https://doi.org/10.1016/j.procs.2013.09.136

Delaney, M. L., Subramony, M. V., \& Durik, A. M. (2014). The joint effects of climates for empowerment and rewards on organizational performance. In Academy of Management Proceedings (Vol. 2014, No. 1, p. 16398). Briarcliff Manor, NY 10510: Academy of Management. https://doi.org/10.5465/ambpp.2014.279

Delgado, GRE, Meza, AKT, Chavez, SAR, \& Murillo, GSA (2018). Demands of People with Disabilities and Empowerment of Resilient Strategies. International Research Journal of Management, IT and Social Sciences , 5 (1), 45-54.

Endriani, A. (2016). Hubungan antara keharmonisan keluarga dengan sikap disiplin siswa. Jurnal Paedagogy, 3(1), 46-53.

Fernandez, S., \& Moldogaziev, T. (2011). Empowering public sector employees to improve performance: does it work?. The American Review of Public Administration, 41(1), 23-47.

Fernandez, S., \& Moldogaziev, T. (2013). Employee empowerment, employee attitudes, and performance: Testing a causal model. Public Administration Review, 73(3), 490-506. https://doi.org/10.1111/puar.12049

Fisher, C. D., Schoenfeldt, L. F., \& Shaw, J. B. (2007). Maintaining Human Resources.

Fitriah, F., \& Sudibya, I. G. A. Pengaruh Pemberdayaan Karyawan dan Kepuasan Kerja terhadap Komitmen Organisasional Sekretariat Perusahaan Daerah Pasar Kota Denpasar. E-Jurnal Manajemen Universitas Udayana, 4(11).

Fu, W., \& Deshpande, S. P. (2014). The impact of caring climate, job satisfaction, and organizational commitment on job performance of employees in a China's insurance company. Journal of Business Ethics, 124(2), 339-349. https://doi.org/10.1007/s10551-013-1876-y

Georgiadis, A., \& Pitelis, C. N. (2012). Human resources and SME performance in services: empirical evidence from the UK. The International Journal of Human Resource Management, 23(4), 808-825. https://doi.org/10.1080/09585192.2011.561236

Gupta, N., \& Shaw, J. D. (2014). Employee compensation: The neglected area of HRM research. Human Resource Management Review, 24(1), 1-4. https://doi.org/10.1016/j.hrmr.2013.08.007

Hakim, A. (2015). Effect of organizational culture, organizational commitment to performance: Study in hospital of district South Konawe of Southeast Sulawesi. The International Journal Of Engineering And Science (IJES), 4(5), 33-41.

Handaru, A. W., Abdillah, S., \& Waspodo, A. A. (2013). Pengaruh karakteristik pekerjaan dan kompensasi terhadap komitmen organisasi pada PT "X" Jakarta. JRMSI-Jurnal Riset Manajemen Sains Indonesia, 4(2), $238-256$.

Harris, C. M., \& McMahan, G. C. (2015). The influence of compensation on leader human capital and unit performance. SAM Advanced Management Journal, 80(1), 33.

Herman, H. M., Huang, X., \& Lam, W. (2013). Why does transformational leadership matter for employee turnover? A multi-foci social exchange perspective. The Leadership Quarterly, 24(5), 763-776. https://doi.org/10.1016/j.leaqua.2013.07.005

Hidayat, R., \& Budiatma, J. (2018). Education and job training on employee performance. International Journal of Social Sciences and Humanities, 2(1), 171-181. https://doi.org/10.29332/ijssh.v2n1.140

Widyastuti, N. P. A., \& Riana, I. G. (2019). Effect of empowerment and compensation on performance of honorary employees mediated by organizational commitments. International Research Journal of Management, IT and Social Sciences, 6(4), 73-85. https://doi.org/10.21744/irjmis.v6n4.652 
Huang, C. C., You, C. S., \& Tsai, M. T. (2012). A multidimensional analysis of ethical climate, job satisfaction, organizational commitment, and organizational citizenship behaviors. Nursing Ethics, 19(4), 513-529. https://doi.org/10.1177\%2F0969733011433923

Ibrahim, M. G., Hilman, H., \& Kaliappen, N. (2016). Effect of job satisfaction on turnover intention: An empirical investigation on Nigeria Banking Industry. International Journal of Organizational and Business Excellence, 1 (2), $1-8$.

Indayati, N. (2012). Pengaruh Keterlibatan Karyawan, Budaya Organisasi, dan Gaya Kepemimpinan terhadap Komitmen Organisasional dalam Meningkatkan Kinerja Karyawan (Studi pada Universitas Brawijaya). Jurnal Aplikasi Manajemen, 10(2), 344-356.

Insan, A., Astuti, E. S., Raharjo, K. U. S. D. I., \& Hamid, D. J. A. M. H. U. R. (2013). The effect of empowerment of the organizational commitment and the job satisfaction of the employees of the National Electricity Company (Ltd.) in South Sulawesi Province Indonesia. Asian transactions on basic \& applied sciences, 3(4), 13-23.

Jaiswal, D., \& Dhar, R. L. (2016). Impact of perceived organizational support, psychological empowerment and leader member exchange on commitment and its subsequent impact on service quality. International Journal of Productivity and Performance Management, 65(1), 58-79. https://doi.org/10.1108/IJPPM-03-2014-0043

Jung, H. S., \& Yoon, H. H. (2014). Antecedents and consequences of employees' job stress in a foodservice industry: Focused on emotional labor and turnover intent. International Journal of Hospitality Management, 38, 84-88. https://doi.org/10.1016/j.ijhm.2014.01.007

Kadarisman, M. (2012). Pengertian dan Filosofi Manajemen Kompensasi.

Karavardar, G. (2014). Perceived organizational support, psychological empowerment, organizational citizenship behavior, job performance and job embeddedness: A research on the fast food industry in Istanbul, Turkey. International Journal of Business and Management, 9(4), 131.

Kasenda, R. (2013). Kompensasi dan motivasi pengaruhnya terhadap kinerja karyawan pada PT. Bangun Wenang Beverages Company Manado. Jurnal EMBA: Jurnal Riset Ekonomi, Manajemen, Bisnis dan Akuntansi, 1(3).

Kazlauskaite, R., Buciuniene, I., \& Turauskas, L. (2011). Organisational and psychological empowerment in the HRMperformance linkage. Employee Relations, 34(2), 138-158. https://doi.org/10.1108/01425451211191869

Kee, L. B., bin Ahmad, R., \& Abdullah, S. M. (2016). Relationship between financial compensation and organizational commitment among Malaysian bank workers. Asian Business Research, 1(1), 75.

Khan, W. A., \& Pop, I. (2010). Boundary-layer flow of a nanofluid past a stretching sheet. International journal of heat and mass transfer, 53(11-12), 2477-2483.

Khanin, K., \& Teplinsky, A. (2013). Renormalization horseshoe and rigidity for circle diffeomorphisms with breaks. Communications in Mathematical Physics, 320(2), 347-377.

Kim, H., \& Sung-Choon, K. (2013). Strategic HR functions and firm performance: The moderating effects of highinvolvement work practices. Asia Pacific Journal of Management, 30(1), 91-113. https://doi.org/10.1007/s10490011-9264-6

Kim, W. G., \& Brymer, R. A. (2011). The effects of ethical leadership on manager job satisfaction, commitment, behavioral outcomes, and firm performance. International Journal of Hospitality Management, 30(4), 1020 -1026. https://doi.org/10.1016/j.ijhm.2011.03.008

Laschinger, H. K. S., Finegan, J. E., Shamian, J., \& Wilk, P. (2004). A longitudinal analysis of the impact of workplace empowerment on work satisfaction. Journal of Organizational Behavior: The International Journal of Industrial, Occupational and Organizational Psychology and Behavior, 25(4), 527-545. https://doi.org/10.1002/job.256

Lo, D., Ghosh, M., \& Lafontaine, F. (2011). The incentive and selection roles of sales force compensation contracts. Journal of Marketing Research, 48(4), 781-798. https://doi.org/10.1509\%2Fjmkr.48.4.781

Mahiri, E. A. (2017). Pengaruh pemberdayaan karyawan terhadap komitmen organisasional pada karyawan perusahaan daerah air minum (pdam) kantor pusat majalengka. MAKSI, 4(2).

Maynard, M. T., Luciano, M. M., D'Innocenzo, L., Mathieu, J. E., \& Dean, M. D. (2014). Modeling time-lagged reciprocal psychological empowerment-performance relationships. Journal of Applied Psychology, 99(6), 1244.

Meyer, J. P., Allen, N. J., \& Smith, C. A. (1993). Commitment to organizations and occupations: Extension and test of a three-component conceptualization. Journal of applied psychology, 78(4), 538.

Meyer, J. P., Stanley, D. J., Herscovitch, L., \& Topolnytsky, L. (2002). Affective, continuance, and normative commitment to the organization: A meta-analysis of antecedents, correlates, and consequences. Journal of vocational behavior, 61(1), 20-52. 
Milgo, A. C., Namusonge, G., Kanali, C., \& Makokha, E. N. (2014). Reward and compensation as a determinant of employee commitment: A survey of KTDA tea factories in Kenya. European Journal of Business and Management, 6(15), 117-125.

Nasution, S. N. (2016). Feminism study on marginalized women in the effort of empowerment. International Journal of Linguistics, Literature and Culture, 2(3), 144-150.

Nawab, S., \& Bhatti, K. K. (2011). Influence of employee compensation on organizational commitment and job satisfaction: A case study of educational sector of Pakistan. International Journal of Business and Social Science, 2(8).

Nouri, H., \& Parker, R. J. (2013). Career growth opportunities and employee turnover intentions in public accounting firms. The British Accounting Review, 45(2), 138-148. https://doi.org/10.1016/j.bar.2013.03.002

Oh, E. H., \& Chung, B. Y. (2011). The effect of empowerment on nursing performance, job satisfaction, organizational commitment, and turnover intention in hospital nurses. Journal of Korean Academy of Nursing Administration, 17(4), 391-401.

Pratiwi, P. (2012). Pengaruh Budaya Organisasi dan Pemberdayaan terhadap Komitmen Organisasi dalam Meningkatkan Kinerja. Jurnal Aset, 14(1), 41-52.

Rustini, N. K. A., Suardikha, I. M. S., \& Astika, I. B. P. (2015). Pengaruh kompensasi dan lingkungan kerja pada komitmen organisasi dan implikasinya pada kinerja pengelola anggaran (studi empiris pada satuan kerja perangkat daerah Pemerintah kabupaten tabanan). Buletin Studi Ekonomi.

Shin, D., \& Konrad, A. M. (2017). Causality between high-performance work systems and organizational performance. Journal of Management, 43(4), 973-997. https://doi.org/10.1177\%2F0149206314544746

Sudharma, K. J. A., Sutrisni, N. K. E., \& Abiyasa, A. P. (2018). Regulation of protection and fulfillment of employee rights of go-jek drivers under Indonesian employment regulation. International Journal of Social Sciences and Humanities, 2(3), 56-62. https://doi.org/10.29332/ijssh.v2n3.193

Suhermin, S. (2018). Pemberdayaan Kerja Profesional Sebagai Mediasi Dukungan Organisasi Dan Pertukaran Pemimpin-Anggota (Lmx) Terhadap Komitmen Organisasional. EKUITAS (Jurnal Ekonomi dan Keuangan), 16(2), 209-229.

UlHaq, M., Jindong, Y., Hussain, N., \& Anjum, Z. (2014). Factors affecting organizational commitment among bank officers in Pakistan. IOSR Journal of Business and Management, e-ISSN-487X, 16(4).

Venkataramani, V., Green, S. G., \& Schleicher, D. J. (2010). Well-connected leaders: The impact of leaders' social network ties on LMX and members' work attitudes. Journal of Applied Psychology, 95(6), 1071.

Vivienne Wu, S. F., Lee, M. C., Liang, S. Y., Chuang, Y. H., Lu, Y. Y., \& Wu, M. P. (2012). Self-efficacy, professional commitment, and job satisfaction of diabetic medical care personnel. Contemporary nurse, 43(1), 38-46. https://doi.org/10.5172/conu.2012.43.1.38

Wallace, E., de Chernatony, L., \& Buil, I. (2011). How leadership and commitment influence bank employees' adoption of their bank's values. Journal of Business Ethics, 101(3), 397-414. https://doi.org/10.1007/s10551-0100728-2

Wang, Q., Weng, Q., McElroy, J. C., Ashkanasy, N. M., \& Lievens, F. (2014). Organizational career growth and subsequent voice behavior: The role of affective commitment and gender. Journal of vocational behavior, 84(3), 431-441. https://doi.org/10.1016/j.jvb.2014.03.004

Wijoyo, P. T. (2016). Pengaruh kompensasi dan komitmen organisasi terhadap kinerja karyawan pt sport glove indonesia. Jurnal Manajemen Bisnis Indonesia (JMBI), 5(4), 325-338.

Yulianti, L., Bramono, K., Mardliyati, E., \& Freisleben, H. J. (2016). Effects of Centella asiatica ethanolic extract encapsulated in chitosan nanoparticles on proliferation activity of skin fibroblasts and keratinocytes, type I and III collagen synthesis and aquaporin 3 expression in vitro. Journal of Pharmaceutical and Biomedical Sciences, 6(5).

Yunita, P. I., \& Saputra, I. G. N. W. H. (2019). Millennial generation in accepting mutations: Impact on work stress and employee performance. International Journal of Social Sciences and Humanities, 3(1), 102-114. https://doi.org/10.29332/ijssh.v3n1.268

Widyastuti, N. P. A., \& Riana, I. G. (2019). Effect of empowerment and compensation on performance of honorary employees mediated by organizational commitments. International Research Journal of Management, IT and Social Sciences, 6(4), 73-85. https://doi.org/10.21744/irjmis.v6n4.652 